\title{
"Managing the household of God" The contribution from management sciences to the sustainability of the church as an organization ${ }^{1}$
}

\author{
Oosthuizen, AJ \\ Central University of Technology, Free State \\ andrej@webafrica.org.za \\ Lategan, LOK \\ Central University of Technology, Free State \\ Llategan@cut.ac.za
}

\begin{abstract}
Church leaders are considered "managers of the household of God" (1 Cor 4: 1, 2) and responsible to give the transforming message of the gospel its rightful place in the organization of the church as well as in the broader society. Despite this imperative, a literature review confirmed that the church as an organization has not been studied extensively by management science, nor do faculties and institutions of theology engage properly with management science. The focus of this article is therefore twofold: to prove that basic management science principles and skills do apply to the church as an organization; and secondly, to identify some of the reasons why the church has not sufficiently incorporated and applied management science principles and skills that can contribute to the effective management of the church. This article contributes to the management of the church as an organization. Although it is commonly acknowledged that different churches and denominations deal with management in different ways, the universality of management skills and principles apply to the church as organization in all its different forms and contexts.
\end{abstract}

\section{Keywords}

Management science, household of God, church as an organization, management and leadership, administration

1 This article is based on the research for a doctoral study on the management of the church in the Department of Business Administration, Faculty of Management Sciences, at the Central University of Technology, Free State. 


\section{Introduction}

Management is an integral part of life and society. Everyone is involved in management at one level or another, whether working alone or in an organization, or just managing your own time. From the earliest recorded times, people began forming groups to accomplish goals they could not achieve individually. Consider for example the management skills required to build the Tower of Babel in Genesis 11. Within this community, people had the common vision of building a great city with a tower reaching to the skies. This obviously required a vision, a plan, large amounts of organizing and controlling of human effort and resources to achieve the desired outcome. After the exile of Israel to Babylon, Nehemiah took the responsibility of rebuilding the wall around Jerusalem. This was a huge managerial challenge, considering the planning, organizing, leading, staffing and controlling of the human as well as other resources necessary to complete the goal of rebuilding the wall around the city. Although the purpose of these texts is not to account for how activities were approached, planned and performed, these parts confirm the observation that management forms part of how a task can be accomplished. The abovementioned activities represent the five functions of management, namely planning, leading, organizing, staffing and controlling (Dyck and Neubert 2008:16). Although in a primitive way, the art and fundamentals of management were present and developed further as humankind developed and techniques and technologies became more sophisticated. Consequently leaders were challenged to manage bigger groups of individuals, which placed an added responsibility on leadership to effectively achieve desired goals (Goleman 2011).

This brought about the natural evolution of basic managerial skills and principles in all of the various social, economic and ecological systems.

Basic management principles and skills are therefore needed to lead an organization when and where people are working together towards a common goal or vision (Rainey 2009). This is applicable to the church too. Within the unique framework of the church as an organization, metaphorically referred to as the body of Christ, the different parts and contributions, together with the allocated resources, also need to be managed effectively and efficiently in order for the organization to realize 
its intended goals and visions. The subsequent paragraphs will build the case why the church needs to be managed and will state why management can assist the church to accomplish its mission. The arguments presented in this article will state the fact that the church as body (read organization) cannot escape the importance to be managed. The drive to manage the church is not new but is in high demand due to the fast changing global, social, political and mobile environment. In fact, the church has to battle for its space in a market-driven economy while it is also grabbling with its sustainable future (Lategan 2005). The point driven home is that managing the church as an organization in line with sound management principles and practices cannot be ignored. Although it is commonly acknowledged that different churches and denominations deal with management in different ways, the universality of management skills and principles still apply to the church as organization in all its different forms and contexts.

This study is not a practical theological study but a study in management sciences focusing on the church. In this sense it is a management study with theological relevance. The study can also be identified as an interdisciplinary study in church management where the emphasis is on management as activity (management) and church as the object of the activity (theology).

\section{Biblical perspectives on the management of the church as an organization}

As a faith-based organization (in other words, the social duty or activity of the church as an organization is founded on the shared belief or faith of the members of the organization), the church is unique in terms of, among others, a distinct origin, distinct message, distinct purpose, distinct ethic, distinct reliance and a distinct mission. It is therefore important that the uniqueness of the church as a faith-based organization needs to be upheld in the conversation and interaction with management science.

Apart from the principles found in the Bible relating to the structure, function, organization and mission of the church as a community of believers, the organization is also demarcated by the external environment, context, confessions and traditions in which it stands. 
Granting the uniqueness of the church as an organization, churches also have much in common with the structure, function and organization of other organizations. Although there are some distinct characteristics that differentiate the church from any other organization, the church is still an organization, sharing some common principles with other enterprises and therefore crying out to be managed effectively and efficiently.

To support the argument that management science principles and skills do apply to the church as an organization, it will be important to trace the understanding and practice of management in the Bible and its specific reference to organized religious practice.

Although there are many references to management in the Old Testament, the focus will primarily be on defining manager/management by identifying passages in the New Testament relating to the understanding of "management" within the framework of management science today. The reason for this is that in the Old Testament temple and society are interwoven. The church is a typical New Testament structure and functions already there in a differentiated societal system.

Because management science is engaging with the church as an organization, the article is not an attempt to do exegesis on all the relevant passages, but rather to define a Biblical understanding of concepts within the context of the Bible. The reason for a New Testament focus is that although the church, as concept and structure, may originate from the Old Testament's concept of the people of God (qahal JHWH) it is essentially a New Testament development.

\subsection{Management in the New Testament}

Two passages are extracted as examples of how the concept of management is used within a Biblical context.

- Matthew 24:45: "A faithful, sensible servant is one to whom the master can give the responsibility of managing his other household servants and feeding them."

- 1 Timothy 3:5: “... but if a man does not know how to manage his own household, how will he take care of the church of God?" 
Although the context of these two passages are different, it is striking that, in both examples, "managing" is used in combination with the term or concept "the household", thus managing the household. This needs further exploiting.

\subsubsection{Manage}

The reason for the combination of the two terms (management and household) lies in the morphological meaning of the word oikovónos (oikonomos). A clearer understanding of the meaning of oikonomos will help to define and understand church management within the context of the New Testament.

"Oikonomos" cognates from "oikos" and "nemo":

- Oikos has the meaning of "house or household".

- Nemo in combination with oikos means "to manage".

Thus, oikonomos literately means "household-manager".

Oikonomos is translated differently throughout the New Testament, according to the context in which it functions. It is commonly translated as steward, servant, manager, superintendent, chamberlain, governor, householder and even treasurer to whom the head of the house has entrusted the management of his affairs, namely to take care of receipts and expenditures and to share out the proper portion to every servant.

To identify some of the different applications of oikonomos, a summary of some texts are given (Lexicon, Thayer's Greek 2011):

- The manager of a farm or estate, an overseer: Luke 12:42; 1 Corinthians 4:2; Galatians 4:2.

- The superintendent of the city's finances, the treasurer of the city:

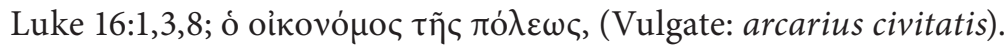

- The treasurers of kings: Romans 16:23.

- Metaphorically, the apostles and other Christian teachers are called

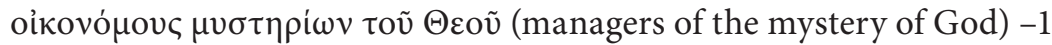
Corinthians 4:1. 
- A bishop (or overseer) is called oỉкovó $\mu$ oৎ $\Theta \varepsilon$ cou, overseer of the Christian theocracy, hereby declaring the managerial role the office of bishop has within the church: Titus 1:7.

- All Christians who rightly use the gifts entrusted to them by God for

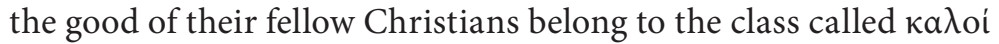

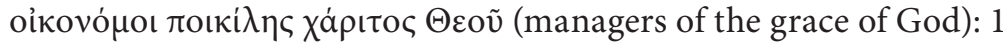
Peter 4:10.

It is evident that oikonomos has a practical as well as spiritual meaning and application. It is interesting to note that there is also reference to different levels of authority and even delegation of responsibility in the Bible when it comes to the managers of the household (1 Pet 2:18, Mt 20:1, Mt 24:45).

In the context of the New Testament, there often was a clear line of authority within social structures: manager, servants and labourers. Jesus delegated authority to His disciples and eventually to the church where ministers, elders and deacons were appointed to help with management and leadership within the household. It is evident that, from a Biblical point of view, the manager is someone entrusted with the responsibility to serve, lead and oversee projects or action and protect or look after the people that are entrusted to them.

\subsubsection{Household}

The common meaning of a household is that of a family or even extended family, including housemates and servants (Acts 16:31, Acts 18:8 and Rom: 16:10).

Within a Biblical context, household also has the collective meaning of a community of faith or the church as defined as a group of believers ( $\mathrm{Gal}$ 6:10, Eph 2:19, 1 Pet 4:17, 1 Tim 3:12 and 1 Tim 3:15).

In these passages, a direct comparison is drawn between the family as a household and the household of God. A church resembles a family. It is indeed larger but also consists of an assemblage of brothers and sisters who are bound together by the same goal and purpose with common feelings and needs.

Therefore, when there is a reference to managing the household of God, it refers to the members of the family as well as to everything else needed for 
the well being and sustainability of the family, i.e. finance, administration, resources, maintenance and protection.

For managing this household with all its different facets, caretakers, leaders or managers are appointed. Interestingly enough, apart from the formal appointment of leaders and managers, each member of the household is also given a very specific place, responsibility and function or role based on the gifts received (Eph 4, 1 Cor 12, 14). These responsibilities are given to accomplish the common goal.

The shared responsibility of the leaders as well as the members of the household is threefold:

1. towards the Head of the church (Jesus Christ)

2. towards other members of the family of Christ (the church)

3. towards those not yet members (people outside the church).

The household of God has well-stipulated principles and rules on how it should function. These rules are founded on the services and responsibilities laid upon the household as well as Christian ethics and are defined in terms of the context and church tradition in which it stands. Reinterpretation of the application of the principles and rules is an ongoing activity necessitated by an ever-changing context. Take, for example, the position of women, their dress code and stipulated behaviour in the organization (1 Tim 2:9) that needs to be interpreted in terms of ancient traditions and societal understanding of the roles of men and women in the congregation. One example of how Christian ethics define the manner in which the church as an organization is managed is the great command to love one another as yourself. This command implies a certain way in which a manager acts, leads, interacts and communicates with people and deals with conflict. Rules and principles are laid down, for example, in terms of conflict between members (Mt 18), court cases between Christians (1 Cor 6 ) and the rights and duties of apostles in terms of remuneration (1 Cor 9). The application of these rules and principles define the unique manner in which the church needs to be managed.

From the Biblical understanding of "household", it is clear that a household resembles a group of people or a family bound together by a common goal 
and purpose. The management of this household is not only the formal responsibility given to different caretakers, leaders, or managers, but it is also the responsibility of each member to accomplish the common goal, based on the gifts the different members received. In pursue of its goals, the household functions on well stipulated principles and rules that demarcate the way the household operates.

\subsubsection{Qualifications of managers}

There are also standards and qualifications that need to be met when someone wants to become a manager of the household of God.

Take for example 1 Timothy 3:1-7 as point of reference. As it is evident that Timothy was to be partly employed in the appointment of suitable officers for the church in Ephesus, and as the kinds of officers referred to were to be permanent in the structures of the church, it was important that a full statement should be put on record, respecting their qualifications and duties. The standards and qualifications of a bishop or manager for the household were set out as follows:

- She/he must be someone of good character - (1 Tim 3:2-3).

- She/he must manage her/his own household well and, by doing so, show that $s /$ he has some managerial skills and is qualified to manage the household of God - (1 Tim 3:4-5).

- She/he must have experience and be of suitable age - (1 Tim 3:6).

- She/he must have a fair reputation among others to be influential (1 Tim 3:7).

A great responsibility is evidently put on being a manager of the household of God. This responsibility holds for the character as well as the experience and reputation of the manager to manage the household of God.

\subsubsection{Administration}

In the New Testament, the office of bishop is often used in relationship with the office of the deacon. Deacon derives from the Greek word diakoneo or diakonia meaning "service". Diakonia can be described as performing a service of official duty or various forms of spiritual or social services. Within the structures of the church or the household of God, the diakonia often has a practical, administrative and service function where the bishop has a leadership or decision-making function. This distinction is well 
known within the ecclesiology and stipulated in, for example, the church order of Protestant churches.

In Acts 6, deacons were appointed to help the apostles in their mission. The deacons had the administrative responsibility of practical service, that is, the daily distribution of food, looking after the widows and orphans and collecting and managing funds for the services provided.

Different translations of the Bible use administration and leadership alternately. It is not only applicable to physical daily tasks but is also used in terms of a spiritual meaning. The following could count as examples of this.

According to the apostle Paul, having the responsibility of administration is a gift (Rom 12:7, Rom 12:8, 1 Cor 12:28, 2 Cor 8:19).

It is evident that administrate has various interpretations within the Biblical context, referring to practical service, the administration of funds and basic leadership. The following conclusions can be made in terms of the Biblical framework of management within the church as an organization:

- An understanding of management in various forms and within different contexts is evident throughout the Bible.

- In its structure and organization, the church is often described as the household of God. The Bible in terms of certain rules and procedures, and standards delineates the household.

- Leadership has a high priority derived from the specified qualifications for leaders or managers of the household.

- Part of managing the household is the practical service and administrative functions that need to be performed.

It is evident that management within the context of the household of God concurs to the basic management functions of planning, leading, organizing, staffing and controlling of human and other resources towards a common goal.

It is also evident that management skills and principles apply to the church as an organization. However the question remains why the church as an organization, and concomitantly the formal education of leaders through faculties of theology and other institutions, is not formally engaging properly or incorporating sufficiently the new developments within 
management sciences in order to lead the organization in an ever-changing environment. This is also evident in the fact that there is no contemporary and comprehensive management literature with theological relevance available on managing the church as an organization within a South African context. In return, the church as an organization is also not studied extensively by management sciences, which is also evident in the absence of contemporary and comprehensive literature within management science on managing the church as an organization within a South African context. Pastors have the responsibility of strategically managing the organization in challenging and ever-changing contexts, of leading, expanding and organizing services and of maximizing opportunities based on the resources available but without any formal education in the underlying fundamentals of management science.

Consequently, because sound managerial principles and skills were not sufficiently incorporated in dealing with the church as an organization, leaders in the church often spend a great deal of time on administrating personnel, members and services. In the process, they confuse it with sound management skills and principles that render leaders capable of recognizing and maximizing opportunities based on the resources available.

\section{The reluctance of the church to engage with management science}

The assumption that basic management principles are not incorporated sufficiently and successfully within the church as an organization has to be found at the source, which is the formal theological training of church leaders. It is expected that, if sound managerial principles were important for the church in all its different facets and structures, it would formally be incorporated within the education of its ministers to lead and manage churches effectively and efficiently.

Very few formal or academic studies were found in which recent managerial skills and business principles were integrated within the organization of churches in the South-African context. Hendriks (2004) advocates the necessity of a multi-disciplinary approach within the formal academic and even informal theology education. He states, “... the church should participate in the academic intellectual aspects of theology. It is 
important that theology should not be done alone in splendid isolation". This underlines the importance of a systems view even when it comes to educating ministers. Hendriks (2004:33) argues as follows:

"Theology should be multi-disciplinary as far as it should relate to other disciplines when addressing issues that confront us. This does not mean that theology has to compromise its normative element."

Burger (1995) acknowledges that the church does not differ much from other organizations and can learn from the social sciences, for example organizational culture and management science. He also states that it is already evident that increasing numbers of church leaders are influenced by publications of well-known businesspersons. The lessons taken from these publications are incorporated in their ministry.

The various theological faculties at Universities, Bible Schools and Institutions in South Africa all accept and adopt an inter-disciplinary approach incorporating sciences such us psychology, law, philosophy, information technology and drama and speech. However, sufficient formal scientific engagement with and incorporation of management science is lacking in the education of pastors as managers of the household of God. Often, managing the church is left to the character, personality and instinct of pastors and is practiced as an art (Kumar \& Sharma 2000:11, Weihrich, 1993), without the science and organized knowledge of management underlying the practice.

In a fast changing environment, the church cannot afford not to engage formally and scientifically with management science in order to equip leaders with the necessary skills and principles to manage the church as an organization effectively and efficiently in the future. Leaving church leaders to rely on own instinct and untested management practices will simply be irresponsible and will end in organizational suicide.

However, there still is reluctance by the church to engage with management science. According to Hunter (2000:23), there are two negative reactions to the idea of church management. They are the following:

1. The church is different and is run on spiritual principles.

2. Ministers are leaders and not managers. 
For church leaders to understand the importance and accept the necessity of basic managerial skills and business principles within the church as an organization, a fundamental understanding of the relationship between management principles and a Biblical understanding of leadership and management is needed. In order to show the relevance of management science for the church, the negative reactions and prejudices will be refuted by an understanding and insight into Biblical church management.

\section{a) Spiritual principles versus scientific principles}

Some church leaders resist insights from the literature of management science on organizational effectiveness because they say the church is different. "Different" is then often qualified by claiming that the church is not an organization. Proponents of this view argue that the church is an organism - the body of Christ - and we are called to run the church on spiritual principles, not on the principles of business and the corporate world.

There are three contentious views in this statement:

1. The distinction between organization and organism is refuted by the definition of management amongst others, as a system interacting with various other systems (Schermerhorn 2010:41, Morgan 2006). In fact, the systems approach, theory and school of thought use organization, system and even the term organism in relationship to one another. Describing the church as an organism therefore does not make the church distinct or unique in regards to other organizations.

2. The uniqueness of the church as a faith-based organization is openly acknowledged and respected, even within management science itself, when the church is commonly referred to and categorized as nonprofitable and faith-based (Drucker 2011). Within this definition, the uniqueness of the church as an organization of faith is acknowledged and even described within management terminology. The uniqueness of the church as a faith-based organization does not therefore imply that basic managerial principles do not apply to the organization of the church. Just as the finance of a church is done based on basic financial principles, other functions within the church should also be run according to the principles of that function, for example personnel, allocation of resources and planning. 
3. The perspective that the church is a "spiritual" organization that can only be governed in a spiritual manner and not in a "worldly" manner does contain a crucial theological discrepancy.

Early Christianity was influenced by a Greek philosophical approach called Gnosticism. Gnosis means knowledge. In essence, Gnosticism can be described as a dualism with the view that the world consists of two fundamental entities, God and the world, correspondingly man and the world. For this reason, Gnostics believed that matter, in particular the human body, is evil and should be avoided and that man's greatest purpose is to focus on spiritual things, practising this dualistic distinction in every aspect of human life (Churton 2005).

For this reason, Gnostic Christians believed that Jesus Christ, as the incarnation of God, did not really take on human flesh and therefore could not have suffered on the cross. The Council of Nicaea in 325 AD branded this view as heresy and insisted on the full humanity of Christ, stating that Jesus Christ was indeed "begotten, not made man", "was crucified," "suffered death and was buried."

The claim that Jesus' body was illusory is commonly referred to as Docetism. Hunter (2000) uses Docetism and applies it to the church as an organism forming the somewhat strange concept of a "docetic ecclesiology". By this, he means the following (Hunter 2000:24):

"As the old Docetism claimed that Jesus' body was not a real human body, though it appeared to be, docetic ecclesiology maintains that the church, the Body of Christ, is not a real human organization, though it appears to be. An orthodox doctrine of the church, however, would affirm the church's full humanity. As Jesus' body was a real human body - as any physician checking for a pulse or a blood pressure reading could have affirmed - so the Body of Christ is a real human organization, reflecting many of the same dynamics and managed by many of the same principles we find in other organizations."

Therefore, the assumption that the church is a spiritual organization and cannot be managed on (so-called secular or worldly) managerial principles is in essence not a practical-theological discrepancy but a deeply rooted misinterpretation of the full humanity of the local church. Although the 
church has a unique character, mission, source and culture, it was, is and always will be a real human organization pleading for sound management.

\section{b) Leaders versus managers}

The second substantial negative reaction surfaces form church leaders who claim, "I am not a manager. I am a leader". Although it is well documented, the distinction between leaders, managers, and administrators needs explanation.

In the literature of leadership, management and administration, these three terms are all unique in their own meaning but also intertwined and interwoven within the general organization of any organization. Take for example the understanding of the difference between leadership and management. Leadership is commonly described as envisioning future innovation, spending time dreaming about long-term goals and expectations. This is supported by Bertocci (2009) when he defines leadership as the combination of characteristics of personality traits in an individual that compels that person to inspire others to achieve goals that they would not normally accomplished without the leader's motivation. He then states that leaders in an organization should have a clear mental picture of where the organization is, where the organization needs to go, and how the organization is going to get there. An important attribute of leadership is therefore to present a clear path for followers to take to accomplish a task or goal. Thus, according to Bertocci (2009:7), the main characteristic of leadership is the following:

“... leaders instinctively seem to know what needs to be done, when it needs to be done, and how it is going to be accomplished; and they get followers to work together to complete the tasks necessary to accomplish the goal."

Kotter (1990) also notes that leadership is about vision, big-picture issues, change and the future. Management, in contrast, is about personnel issues, organizational design and structure, staffing, control and human resources issues. Kozak (1998) supports this by stating that managers deal with systems, processes, budgets, equipment and "things" whilst leaders deal with visions and people. 
It is clear that there is a distinction between leadership and management based on functions. Leaders visualize what has to be done, mentally develop a clear path to accomplish the change in the situation and then communicate what has to be done to their followers. Managers, on their part, have to plan, organize, structure and evaluate or control (Bertocci 2009:12).

Hunter (2000:26) applies the distinction between leadership, management and administration to the context of the church as follows:

"A leader communicates the church's vision, purpose, and direction and mobilizes people's energy in support of it. A manager deploys people (and resources), through specific roles, jobs, and tasks, to achieve the mission's purpose and sees to it that the organization permits and helps the people to succeed. An administrator facilitates the workflow of the organization and attends to its efficiency. The obsession of the first role is direction, the second is effectiveness, and the third is efficiency."

Although there is a clear distinction between leadership, management and administration, successful organizations need all three functions (Kozak 1998). Dreams and visions (leadership) need to be implemented in structures (management), and resources need to be utilized effectively and efficiently (administration) in turning dreams into realities.

Therefore, the general assumption that ministers are leaders and not managers is refuted on the scientific basis of the alternation and interaction of the three terms, leader, administrator and manager. Within the managerial paradigm, any leader needs administrative and management skills, and most pastors are in any case engaged in all three functions, therefore refuting in practice the argument of leaders and managers.

There is often a shortcoming in the leadership and management skills of ministers in the church. Some can envision the future but do not have the management or administrative skills to structure or implement the vision. Others can let a governing board make decisions and are successful in implementing and structuring those efforts but struggle to control and evaluate efforts, therefore lacking administrative skills. Some churches are over-led and under-managed. Others are over-administrated and underled whilst others are over-managed but lack leadership. 
Hunter (2000:28) confirms this by stating the following about the church:

"[It] attracts a disproportionate number of people who can lead, but cannot (yet) manage. This is a long-standing problem in the judeoChristian tradition. Indeed, this was the very problem that hounded Moses and the Israelites until Jethro stepped in."

This is the result of the absence of basic management knowledge and skills and the random, non-factual reaction of ministers to set leadership against management and administration. Better knowledge will bring an understanding of the necessity and interaction of leadership, administration and management in the different levels of organization, bringing a holistic approach to management science within the church as an organization.

\section{Conclusion}

It is the expected responsibility of leaders of the church as an organization to plan, lead, organize, staff and control human and other resources to achieve the organizational goals effectively and efficiently in a highly specialized and scientific environment. The result of the reluctance to formally engage with the church as an organization and with management science is an organization that is increasingly struggling with basic management deficiencies. The church as an organization is exposed to insufficient education in management principles and skills through formal education that, in turn, results in leaders that often struggle to perform the basic managerial tasks expected of them. Consequently, the lack of basic management principles and skills negatively affect the efficiency and effectiveness of the organization in pursue of its goal and intent.

In a consumer society, people look at the way in which businesses are run, they work in highly effective companies, expect change and good service, but then often find the church struggling in performing basic services within outdated traditional structures and management styles. This is not only the effect of the consumer society but also the fruits of a certain ecclesiological framework where church members expects to be served by a pastor as the sole paid employee of the church responsible for attaining goals. Too often, pastors take up this responsibility by means of a leadership style not conducive for member participation and innovation. 
In order to address the stated problem, current as well as future leaders of the church as an organization needs to engage with management principles and skills in order to manage the household of God more effectively and efficiently.

\section{Bibliography}

Bertocci, DI 2009. Leadership in organizations: There is a difference between leaders and managers. New York: University Press of America.

Burger, C 1995 Gemeentes in transito: Vernuwingsgeleenthede in 'n oorgangstyd. Kaapstad: Lux Verbi.

Churton, T 2005. Gnostic philosophy: From ancient Persia to modern times. Rochester, VA: Inner Traditions.

Drucker, PF 2011. Managing the non-profit organization. New York: Butterworth-Heineman.

Dyck, B \& Neubert, M 2008. Management: Current practices and new directions. Boston: Cengage Learning.

Goleman, D 2011. What makes a leader? Harvard Business Review's 10 Must Reads on Leadership. 1:1-22.

Hendriks, JH 2004. Studying congregations in Africa. Wellington: Lux Verbi.

Hunter, G 2000. Leading and managing a growing church. Nashville: Abingdon Press

Kotter, JP 1990. What leaders really do. Harvard Business Review. July:104-111.

Kozak, DC 1998. Leadership. Gannon University Magazine. Winter:2-7.

Kumar, A \& Sharma, R 2000. Business management. New Delhi:Atlantic Publishers and Distributors.

Lategan, LOK 2004. Remarks on the church in the consumer society. Acta Theologica 24(2):68-79. 
Lexicon, Thayer's Greek, 2011. Biblesoft Inc. http://www.biblestudytools.com/ lexicons/greek/kjv/ [Online] [Accessed: 20 February 2012] From Morgan, G 2006. Images of organization. London: Sage Publications.

Rainey, HG 2009. Understanding and managing public organizations:

Essential texts for nonprofit and public leadership and management. San Francisco: John Wiley \& Sons.

Schermerhorn, J 2010. Management. Hoboken: John Wiley \& Sons.

Weihrich, H 1993. Management: Science, theory, and practice. San Francisco: University of San Francisco. 